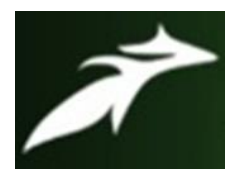

Lingam Orpha Vijaya Sunanda et al, International Journal of Advances in Agricultural Science and Technology, Vol.8 Issue.8, August-2021, pg. 134-146

ISSN: 2348-1358

Impact Factor: 6.057

NAAS Rating: 3.77

\title{
Constraints faced by Progressive Farmers for Effective Utilization of Information through ICT and Suggestions for Better ICT Services in Kurnool District of Andhra Pradesh
}

\author{
Lingam Orpha Vijaya Sunanda \\ M.Sc. Ag. (Agricultural Extension and Communication) \\ Dr. Syed H. Mazhar \\ Associate Professor, Department of Agricultural Extension and Communication, SHUATS (Prayagraj) \\ Prof (Dr.) Ms. Jahanara \\ Professor and Head, Department of Agricultural Extension \& Communication, SHUATS (Prayagraj) \\ DOI: 10.47856/ijaast.2021.v08i8.015
}

\begin{abstract}
Information and Communication Technology (ICT) is an important source for sharing and receiving of agricultural information. The present study explored the constraints faced by farmers and suggestions for effective utilization of ICT services for agricultural information. The study was conducted in all villages of Nandyal Mandal of Kurnool District of Andhra Pradesh. 2021. Responses from the 120 farmers were collected through well-structured interview schedule. It was revealed that that lack of knowledge about ICT tools, poor condition of equipment, relevant information not received in time and awareness of new ICT service among farmers about the use of ICTs for the educational and agricultural purpose were the major constraints in ICT use. All these constraints can be overcome by implementing suggestions by farmers like; proper and improved infrastructural facilities at the village level, providing relevant information at a time and skill development updating with training, creating awareness regarding use of ICTs for educational and agricultural purpose.

The data collected were analyzed using descriptive statistics and regression analysis in finding relationships between variables. The findings show that most of the farmers in Nandyal Mandal that use ICTs as a source of agricultural information
\end{abstract}

Keywords: ICT, Farmers, Agriculture, Constraints 


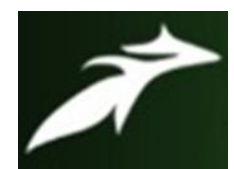

Lingam Orpha Vijaya Sunanda et al, International Journal of Advances in Agricultural Science and Technology, Vol.8 Issue.8, August-2021, pg. 134-146

ISSN: 2348-1358

Impact Factor: 6.057

NAAS Rating: 3.77

\section{Introduction}

The world is moving quite rapidly. India is known as an IT superpower but ironically, the tremendous progress made by IT sector has largely managed to bypass the domain of agriculture of India during last three decades. There is a humongous potential for Information and Communication Technology in Agriculture to enhance the efficiency of farming operations, monitoring of diseases and pests, price discovery, farm advisories, resource management and market connectivity, which can expeditiously escalate farm profitability. ICT will play an important role in translating Hon'ble Prime Minister's vision of empowering farmers into action by connecting them with programs, schemes, subsidies and markets.

The changes are evident in every aspect of life, It is politics, culture or economy and one of the most important change drivers in the technology. Information is important for technology growth. Information consists of the compilation of facts collected by different means of communication and plays a critical role in the Fast-growing generation. At the same time, technology allows quick and quick collection of information fast. Information and technology together have developed a new division called Information Technology (IT). The relevance of ICTs for Agricultural Development in general and for Agricultural Extension is extremely high for a country like India.

Agriculture is the most important sector in Indian economy along with it also play significant role to sustain the livelihood security for millions of farmers in the country. Agriculture contributes in India's economy as $54.6 \%$ of the population is engaged in agriculture and allied activities (census 2011) and it contributes 17.4\% to the country's Gross Value Added for the year 2016-17 (at current prices). Research, extension system and farmer efforts have all contributed significant food production 50 million tonnes in 1950-51 to a land mark achievement of an 4th estimated 275.68 million tonnes in 2016-17 (Annual Agricultural Report, MoAC \& FW, GoI, 2017- 18). The total demand for food grains is projected to touch 280.6 million tonnes by the year 2020-21 (Ramesh Chand, 2009) To achieving this demand goal will necessitate a growth rate of nearly two per cent per annum in food grain production (Singh, 2011) and the agriculture sector needs to grow at a targeted four per cent per annum. Cultivation area and water resources are almost reaching their limits; hence, achieving food security heavily relies on "Knowledge Resource" (Saravanan, 2011). Estimates indicated that 60 per cent of farmers do not access any source of information for advanced agricultural technologies resulting in huge adoption gap (NSSO, 2005).

Agricultural extension emerged as a field in 1960s with an objective to provide support and guidance to rural farmers and reduce information asymmetries related to technology adoption in both developed 


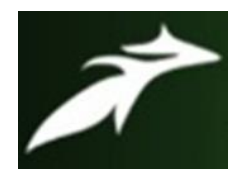

Lingam Orpha Vijaya Sunanda et al, International Journal of Advances in Agricultural Science and Technology, Vol.8 Issue.8, August-2021, pg. 134-146

ISSN: 2348-1358

Impact Factor: 6.057

NAAS Rating: 3.77

and developing countries. Agricultural scientists helped farmers by sharing innovative technologies and effective strategies to increase yields through extension services (Singh, 2002). Agricultural extension is considered vital for growth in agriculture sector. Objective of agriculture extension was to simplify delivery of strategic knowledge and information to farmers in an effective manner.

Seasonal variability in weather patterns, deterioration in soil conditions and sporadic climatic events such as drought, floods, pest and disease outbreaks complicate the decision making process of the farmers and influences their information requirements. Up-to-date information allows farmers to survive and even benefit from these changes. Providing such knowledge can be challenging as the information must be tailored specifically to distinct conditions. Given these challenges the arrival of Information and Communication Technology (ICT) is well timed. The benefits of ICT to contribute for improving agricultural productivity has been previously proposed (Armstrong et al., 2010, Armstrong et al., 2011, Armstrong et al., 2012a,b). As a result both public and private sectors have long been on the search of effective solutions to address both the long and short term challenges in agriculture including how to answer the abundant information needs of farmers. ICT is one of these solutions that have recently unleashed incredible potential to improve agriculture in developing countries. With the growing mobile, wireless, and Internet industries, ICT has found a position even in poor smallholder farms and in their activities. The role of Information and Communication Technologies (ICT) to support agriculture production system has been investigated by many government agencies and university research departments and has proved to play a vital role in the transfer of technology and to share the modern agriculture practices with the farmers. However many of these farmers are not completely utilizing the full potential of the ICT (Jain et al., 2010). A number of studies have observed that for many rural areas the use of ICT such as personal computers and mobile phones has continued to increase in recent years by agricultural industry stakeholders. (Mwakaje, 2010; Krishna et al., 2005; Kalusopa, 2005).

ICTs, tool like mobile phones has impressive penetration in many of the developing countries changing the agricultural communication process and mobile phones have made personal communications readily accessible, for the first time, to women and men, poor and prosperous, rural and urban dwellers in developing as well as in industrial countries (Colle, 2010). ICT is helpful in providing accurate, timely, relevant information and advice to the farmers, thereby facilitating favorable platform for more remunerative agriculture. By using of ICT ${ }^{\mathrm{ee}} \mathrm{s}$ service farmers can choose any medium to seek the relevant information and advice. It can play a miracle change in the field of extension services. The timely availability of right information for its right purpose in its proper 


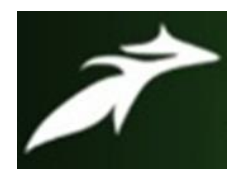

Lingam Orpha Vijaya Sunanda et al, International Journal of Advances in Agricultural Science and Technology, Vol.8 Issue.8, August-2021, pg. 134-146

ISSN: 2348-1358

Impact Factor: 6.057

NAAS Rating: 3.77

utilization of major inputs required for farming. Information and Communication Technology (ICT) can act as a driving force in the agricultural development process (Chahal et al., 2012). So realizing the importance of $\mathrm{ICT}^{\mathrm{ee}} \mathrm{s}$ as complementary mode with extension service to increase the reach to grass root level. Hence, in this paper an attempt to study the socio economic profile of progressive farmers and their contribution for agriculture development.

\section{Objective}

To find out the constraints faced by the respondents in utilization of information through ICT and their suggestions for better ICT services.

\section{Review of Literature}

Ajayi A. O. (2016) claimed that through this ICT, farmers can obtain information that they can use to improve their agricultural income, and their lifestyle. It has been suggested that farmers with large land can use ICT more efficiently than the farmers with small land. However, it is necessary to comprehend how the farmers make use of ICT.

Manoj Sharma, Gagandeep Kaur and M S Gill (2016) Though the progressive farmers are keen to get relevant and timely information and are in possession of ICT tools, their use in agriculture is low. It was observed that the major gap of these tools for fetching is non availability of relevant information and lack of skill on part of farmers. The utility of available infrastructure is also an issue e.g. the farmers either don't have computers or those who have, don't have internet connection which limits its utility. Inconsistent power supply in rural areas limits the use of mass media. Lack of awareness regarding source of information. Other causes are the lack of a policy and regulatory environment and the low progress in research on use ICT and mobile infrastructure for agriculture purposes

Avilesh et al., (2017) suggested that collaboration of government and non-government organisations to sensitise farmers to produce more agricultural products through agricultural policies and schemes, ICT course related to agriculture should be provided to farmers and broadcasting of local agricultural programmes in local language on television or information through mobile phones.

Muhammad Ziaul Hoque (2021) Low access to electricity connection and their interrupted supply, lack of sales and customer delivery center for ICT-based tools in the rural areas, and insufficient 




Lingam Orpha Vijaya Sunanda et al, International Journal of Advances in Agricultural Science and Technology, Vol.8 Issue.8, August-2021, pg. 134-146

ISSN: 2348-1358

Impact Factor: 6.057

NAAS Rating: 3.77

training and awareness building initiatives are major challenges for effective utilization of ICTs by the rural Charland farmers.

\section{Research Methodology}

Research methodology is the path through which researchers need to conduct their research. It shows the path through which these researchers formulate their problem and objective and present their result from the data obtained during the study period. Purpose of this methodology is to satisfy the research plan and target devised by the researcher.

The present study will be conducted in Kurnool district of Andhra Pradesh. Kurnool district has been selected for present course of investigation on the basis of following reasons.

This district derives its name from its chief town Kurnool the capital of former Nawabs, Capital of Andhra Pradesh State from 1st October 1953 to 1st November, 1956 and at present the headquarters of the district. The name Kurnool is said to have been derived from "Kandanavolu".

Kurnool District lies between the northern latitudes of 140 54' and 160 18' and eastern longitudes of $76058^{\prime}$ and 790 34'. The altitude of the district varies from $100 \mathrm{ft}$ above the mean sea level. This district is bounded on the north by Tungabhadra and Krishna rivers as well as Mahabubnagar district of Telangana State, on the south by Kadapa and Anantapur Districts on the west by the Bellary district of Karnataka State and on the east by Prakasam District.

The district ranks 10 in population with 40,53,463 People accounting for $4.63 \%$ of the total Population of the state as per 2011 Population Census, while in area it occupies the 3rd place with $17658 \mathrm{Sq}$. km., which account for $6.41 \%$ of the total area of the state.

At present Kurnool District comprises 3 Revenue Divisions, 55 Revenue Mandals, One Municipal Corporation, 4 Municipalities, 4 Nagara Panchyats, 889 Gram Panchayats, 921 Revenue Villages. District normal rainfall of the year is $670.5 \mathrm{~mm}$.

The total Geographical area of the district is 17.658 lakh ha. During the year 2016-17 the area covered by forest is 3.406 lakh ha. Which forms $19.29 \%$ to the total geographical area. The net area sown is 8.52 lakh ha, forming $48.26 \%$ to the total geographical area. The total cropped area in the district is 9.17 lakhs ha. The area sown more than once during the year is 0.65 lakh ha. The gross cropped area of the district is 9.17 lakh ha. Out of which 2.09 lakh ha, irrigated through canals, tanks, wells and other sources during 2016-17.

Kurnool is the judicial capital of Andhra Pradesh, India. It is the 5th largest city of Andhra Pradesh, India. 


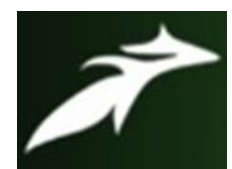

Lingam Orpha Vijaya Sunanda et al, International Journal of Advances in Agricultural Science and Technology, Vol.8 Issue.8, August-2021, pg. 134-146

ISSN: 2348-1358

Impact Factor: 6.057

NAAS Rating: 3.77

\section{Research Design}

Research design is the entire process of planning and carrying out research. Kerlinger (2004) defined "Research design is the plan, structure, and strategy of investigation so as to obtain answers to research questions and to control variance". Descriptive research design was used for the present study. Descriptive research design was used for the present study. Descriptive research includes survey and fact-finding enquires of different kinds. The major purpose of descriptive research is description of the state of affairs as it exists at present. Descriptive research design was followed.

\section{Sampling plan}

Multistage sampling procedure was followed.

A) Selection of district: Kurnool district of state Andhra Pradesh was selected purposely for the present study because maximum number of progressive farmers are using ICTs.

B) Selection of division: Out of three divisions, one division namely Nandyal was selected randomly which were shown in figure 3.1 for the study.

C) Selection of Mandal: There are 55 Mandals in Kurnool district, out of these Nandyal Mandal was selected.

D) Selection of village: There are 20 villages in Nandyal Mandal. All the villages were selected randomly for the present study.

E) Selection of respondents: One hundred and twenty respondents were selected randomly for the present study.

\section{Methods and tools of data collection}

The primary data was collected from the respondents through pre-structured interview schedule by personal interview method in an informal atmosphere. Interview schedule Taking the consideration of the objectives of study a well-structured interview schedule was prepared. Before finalizing the schedule, it was pre-tested in non-sampling area to probe in to relevancy of the schedule to suit the area under study.

Operationalization and measurement of variables

Variables and their measurements the appropriate variables for the present study were prepared based on the objectives of the study, review of literature, discussion with experts and also the observations 


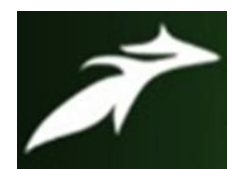

Lingam Orpha Vijaya Sunanda et al, International Journal of Advances in Agricultural Science and Technology, Vol.8 Issue.8, August-2021, pg. 134-146

ISSN: 2348-1358

Impact Factor: 6.057

NAAS Rating: 3.77

made by the researchers. Operational definitions of the variables According to Kerlinger, an operational definition is a specification of the activities of the researchers in measuring a variable or in manipulating it. The operational definitions of the variables taken under study are given below. Based on the objectives of the study, variables were identified with the help of experts, and review of relevant literature.

Statistical tools and analysis of data

The data was further analyzed for testing the significant effects of the parameters understudy.

\section{Frequency}

Frequency is the number of occurrences of a particular event. Statically, frequency (fi) of an event I is the number ni of times the event occurred in the experiment or the study.

\section{Percentage}

For making comparisons, percentages were used in descriptive analysis. Percentages are calculated by multiplying 100 with the frequency of a particular cell and dividing by the total number of respondents in that particular cell.

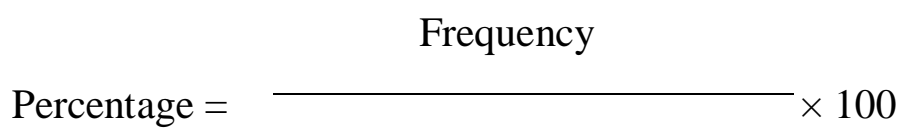

Total number of respondents

a) Arithmetic Mean (A.M)

The mean is the epitomized value arrived by dividing the sum ofobservations by the total number of observations. 


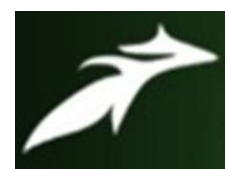

Lingam Orpha Vijaya Sunanda et al, International Journal of Advances in Agricultural Science and Technology, Vol.8 Issue.8, August-2021, pg. 134-146

ISSN: 2348-1358

Impact Factor: 6.057

NAAS Rating: 3.77

$$
\overline{\sum X i}=N
$$

Where,

$\mathrm{Xi}=$ Observation Score

$\mathrm{N}=$ Total number of observations

$\mathrm{X}=$ Mean Score

a) Standard Deviation (S.D.)

The square root of the mean of the squared deviations of individual values from their mean is standard deviation of that set of values. The formula used for standard deviation was as below

S.D. $=\frac{\sqrt{ } \sum(\mathrm{Xi}-\mathrm{X})^{2}}{\mathrm{~N}}$

Where,

S.D. = Standard deviation

$\sum=\operatorname{Sum}$

$\mathbf{X}_{\mathbf{i}}=$ Individual score

$\mathbf{X}=$ Mean of sample

$\mathbf{N}=$ Total no. of respondents 


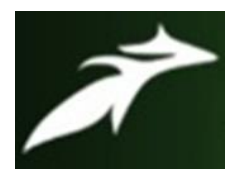

Lingam Orpha Vijaya Sunanda et al, International Journal of Advances in Agricultural Science and Technology, Vol.8 Issue.8, August-2021, pg. 134-146

ISSN: 2348-1358

Impact Factor: 6.057

NAAS Rating: 3.77

b) Correlation coefficient:

To find out the degree of linear relationship between socio-psychoeconomical and communicational variables of the respondents and their extent of increase in production level of chickpea crop, correlation coefficients were worked out by using the following formula :-

$$
r=\frac{\sum X Y-\frac{\left(\sum X\right)\left(\sum Y\right)}{n}}{\sqrt{\left(\sum X^{2}-\frac{\left(\sum X\right)^{2}}{n}\right)\left(\sum Y^{2}-\frac{\left(\sum Y\right)^{2}}{n}\right)}}
$$

Where,

$\mathrm{n}=$ Number of observations being correlated,

$\sum \mathrm{xy}=$ Sum of products of $\mathrm{x}$ and $\mathrm{y}$

$\mathrm{x} \& \mathrm{y}=$ the variables being correlate.

$\sum \mathrm{x}=$ Summation over all the cell entries of the first variable,

$\sum \mathrm{y}=$ Summation over all the cell entries of the second variable,

$\sum \mathrm{x} 2=$ Sum of all the squared values of each cell of the first variable

$\sum$ y2 = Sum of all the squared values of each cell of the second variable

The significance of the calculated $r$ was tested by using Fisher \& Yates table of values of $r$ for different levels of significance. 




Lingam Orpha Vijaya Sunanda et al, International Journal of Advances in Agricultural Science and Technology, Vol.8 Issue.8, August-2021, pg. 134-146

ISSN: 2348-1358

Impact Factor: 6.057

NAAS Rating: 3.77

RESULTS AND DISCUSSION

CONSTRAINTS FACED BY RESPONDENTS IN UTILIZATION OF INFORMATION THROUGH ICT AND SEEK THEIR SUGGESTIONS FOR BETTER ICT SERVICES.

An attempt was made to find out the constraints perceived by the farmers in utilizing ICTs and presented in table Ranks were given based on frequency and percentage.

Table: Distribution of respondents according to their Constraints faced by respondents.

\begin{tabular}{|l|l|c|c|c|}
\hline \multicolumn{1}{|c|}{ CONSTRAINTS } & \multicolumn{3}{c|}{ RESPONSE } \\
\cline { 3 - 5 } & & F & P (\%) & RANK \\
\hline $\mathbf{1 . n}$ & High cost of latest farm technology like Drones. & 107 & 89.16 & $1^{\text {st }}$ \\
\hline $\mathbf{2 .}$ & Lack of infrastructure like service centers of ICTs in villages. & 101 & 84.16 & $2^{\text {nd }}$ \\
\hline $\mathbf{3 .}$ & Difficulty in understanding the language of ICTs gadgets. & 96 & 80.0 & $3^{\text {rd }}$ \\
\hline $\mathbf{4 .}$ & Lack of training programmes on ICT usage. & 91 & 75.83 & $4^{\text {th }}$ \\
\hline $\mathbf{5 .}$ & Content are not available in local language. & 82 & 68.33 & $5^{\text {th }}$ \\
\hline $\mathbf{6 .}$ & Inadequate internet facilities. & 74 & 61.6 & $6^{\text {th }}$ \\
\hline $\mathbf{7 .}$ & Lack of sufficient skills in usage of ICTs. & 59 & 49.16 & $7^{\text {th }}$ \\
\hline $\mathbf{8 .}$ & Lack of knowledge about helpline numbers. & 45 & 37.5 & $8^{\text {th }}$ \\
\hline $\mathbf{9 .}$ & Lack of trust. & 41 & 34.16 & $9^{\text {th }}$ \\
\hline $\mathbf{1 0 .}$ & Low level of education. & 37 & 30.83 & $10^{\text {th }}$ \\
\hline $\mathbf{1 1 .}$ & Lack of awareness of benefits of ICTs. & 19 & 26.66 & $11^{\text {th }}$ \\
\hline $\mathbf{1 2 .}$ & Lack of uninterrupted power supply. & & $12^{\text {th }}$ \\
\hline
\end{tabular}

The table represents the constraints faced by the respondents.

Among constraints, high cost of latest farm technology like Drones rank first followed by lack of infrastructure like service centers of ICTs in villages, Difficulty in understanding the language of ICTs gadget, Lack of training programme on ICT usage, Content are not 


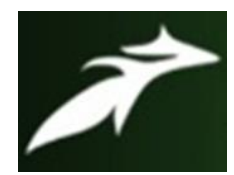

Lingam Orpha Vijaya Sunanda et al, International Journal of Advances in Agricultural Science and Technology, Vol.8 Issue.8, August-2021, pg. 134-146

ISSN: 2348-1358

Impact Factor: 6.057

NAAS Rating: 3.77

available in local language, Inadequate internet facilities. Lack of sufficient skills in usage of ICTs, Lack of knowledge about helpline numbers, Lack of trust, Low level of education, Lack of awareness of benefits of ICTs, Lack of uninterrupted power supply.

\section{SUGGESTIONS}

They have suggested that subsidies for the latest Technologies like drones need to be issued by Government, broadcasting should be done properly, provide information in suitable time, proper extension strategies and training to be provided related to ICT tools which will improve the utilization of ICTs. This shows that most of the farmers were interested in receiving information it is found that some farmers were being progressive using latest ways of farming due to high innovativeness and risk orientation and they were having idea about information disseminated through ICT. Beyond giving farmers more and better information, their choice sets can also be expanded. The ICT infrastructure may also be used to bring down the communication barriers and gives Right Information at Right Time to farmers. Government through the relevant ministry should create awareness on latest farm technologies like Drones to progressive farmers and their importance through ICTs. Intensive training and frequent awareness of ICTs such as internet and availability of fresh, real time data on helplines, mobile apps is required and adequate infrastructure in rural areas for enhancement of ICT.

\section{CONCLUSION}

It is concluded that major constraints faced by the respondents were high cost of latest farm technology like Drones, lack of skill in usage and lack of complete information on the topic. Television and Mobile was the most used ICT for the farmers to get the agriculture information easily. They have suggested that subsidies for the latest Technologies like drones need to be issued by Government, broadcasting should be done properly, provide information in suitable time, proper extension strategies and training to be provided related to ICT tools which will improve the utilization of ICTs. This shows that most of the farmers were interested in receiving information it is found that some farmers were being progressive using 


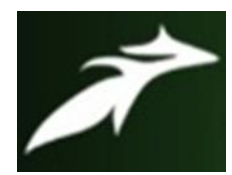

Lingam Orpha Vijaya Sunanda et al, International Journal of Advances in Agricultural Science and Technology, Vol.8 Issue.8, August-2021, pg. 134-146

ISSN: 2348-1358

Impact Factor: 6.057

NAAS Rating: $\mathbf{3 . 7 7}$

latest ways of farming due to high innovativeness and risk orientation and they were having idea about information disseminated through ICT. Beyond giving farmers more and better information, their choice sets can also be expanded. The ICT infrastructure may also be used to bring down the communication barriers and gives Right Information at Right Time to farmers. Government through the relevant ministry should create awareness on latest farm technologies like Drones to progressive farmers and their importance through ICTs. Intensive training and frequent awareness of ICTs such as internet and availability of fresh, real time data on helplines, mobile apps is required and adequate infrastructure in rural areas for enhancement of ICT.

\section{REFERENCES}

[1]. Aldosari, F., Shunaifi, M.S.A., Ullah, M.A., Muddassir, M and Noor, M.A.(2017).Farmers Perception regarding the use of Information and Communication Technology (ICT) in Khyber Pakhtunkhwa, Northern Pakisthan.Journal of the Saudi Society of Agricultural Sciences.1-7

[2]. Armstrong, L.J and Gandhi, N. (2012). Factors Influencing the Use of Information and Communication Technology (ICT) Tools by the Rural Farmers in Ratnagiri District of Maharashtra, India. Agro-Informatics and Precision Agriculture.50-63.

[3]. Avilesh, J., Shane, H and Arvind, R. (2017). Accessibility and Relevance of Extension Methods and Information and Communication Technologies among Farmers in Mauritius. International Journal of Agricultural Extension and Rural Development Studies.4(1):31-43.

[4]. Dhaka, B.L. And Chayal, K. (2010). Farmers Experience with ICTs on Transfer of Technology in Changing Agri-rural Environment. Indian Research Journal Extension Education.10 (3):114-118.

[5]. Hasan, S and Sharma, A.(2011). Print Media Utilization Pattern among Homemakers. Global Media Journal -Indian Edition / Summer Issue.1-17

[6]. Kabir, K.H and Roy, D.2015. Preferences of ICT tools by the Upazila Agriculture Officers (UAOs) for the Information Exchange in Bangladesh. Journal of Agriculture, Forestry and Fisheries.4 (2): 59-65.

[7]. Nnenna, E.A. 2013. Access and Application of Information and Communication Technology (ICT) among Farming Households of South East Nigeria. Agriculture and Biology Journal of North America.4 (6): 605-616.

[8]. Ogbonna, O.I and Agwu, A.E. 2013.Access and use of Information Communication Technologies by Rural Farmers in Enugu North Senatorial Zone, Enugu state. Scholarly Journal of Agricultural Science.3 (7): 264-270.

[9]. Saikia, P., Das, M.D and Deka, M.B. 2016. Use of Information and Communication Technology by Farmers to Access Agricultural Information in Jorhat District of Assam, India. Asian Journal of Agricultural Extension, Economics \& Sociology.13 (3):1-6. 


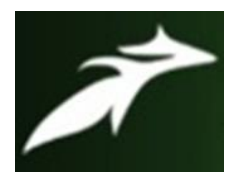

Lingam Orpha Vijaya Sunanda et al, International Journal of Advances in Agricultural Science and Technology, Vol.8 Issue.8, August-2021, pg. 134-146

ISSN: 2348-1358

Impact Factor: 6.057

NAAS Rating: 3.77

[10]. Samatha, J. 2011. Extent of use of ICTs in selected crops by the farmers of Guntur district of Andhra Pradesh. M.Sc. (Ag.)Thesis. Acharya N.G.Ranga Agricultural University, Hyderabad (India)

[11]. Sangha, A.S and Rakshit, S.K. 2010. Role of ICT in the Agriculture Sector: A Study of Progressive Farmers, Malwa Region, Punjab, India. AFITA International conference, 47-53.

[12]. Sobalaje, A.J and Adigun, G.O. 2013. Use of Information and Communication Technologies (ICTs) by Yam Farmers in Boluwaduro Local Government Area of Osun State, Nigeria. Library Philosophy and Practice (e-journal).1-19. 